\section{The mushrooming brain}

Ryan J. Huxtable

Food of the Gods: The Search for the Original Tree of Knowledge. By Terence McKenna. Bantam: 1992. Pp. 300. \$21.50.

IN the beginning were the great savannahs of Africa, on which presapient hominids, with brains one-third the size of ours, eked out marginal existences as gatherers and inefficient hunters. From the excrement of grazing ruminants grew mushrooms, Stropharia cubensis, containing the hallucinogen psilocybin, which pre-man sampled. And lo! Visions came onto him, and selfconsciousness, and speech. The increased insight allowed by the "chemical binoculars" of the mushroom made for more successful hunting and triggered a rapid increase in brain size. Thus from out of the mushroom was born man. The sexual arousal caused by psilocybin allowed him to reproduce better, to the detriment and extinction of the other non-turd-examining hominids. And man lived at peace in the world.

But woman learned to grow plants and embraced a sedentary life in her garden. She no longer ate the mushrooms, because the hallucinations made her oversleep in the morning instead of hoeing the fields. And thus began the great retreat from the natural world, which brought all the evils of history on mankind. And the ice age ended, and the glaciers marched north from Eurasia, bringing desiccation to the grasslands of Africa. So man was forced east of Eden - into Asia - where there was a dearth of mushrooms. This drove the continued evolution of language, leading to the emergence of the ego, from whence comes evil. Or so according to Terence McKenna.

For proper comprehension, Food of the Gods must be viewed not as science, or even sociobiology, but as a creation story, an exercise in reshaping old myths for modern society. It is a retelling of the Fall of man, and original sin, for the Fall came from the same causes that allowed our evolution from proto-humans. In essence, it is a morality tale, the author himself using the phrase, "a pharmacological pilgrim's progress". So, for all the pseudoscientific trappings, perhaps the arguments in this book are no more to be taken literally than any other creation story. If anything, Food of the Gods is poetry disguised in the language of

science. Indeed, we are treated to a dithyramb on the Joycean pleasure of botanical descriptions: "Leaves . . . sessile, linear-lanceolate or lanceolate, acute or acuminate.

So McKenna would have us believe that all came from the mushroom. The radical nature of his argument is perhaps shown by his describing the inventor of

\begin{abstract}
a
\end{abstract}

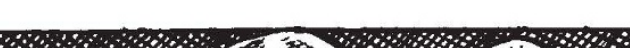

mycolatry, R. Gordon Wasson, as conservative in his views on fungi. Simplistic as it may seem, the book is thoughtprovoking. The mushroom gave us, says McKenna, self-awareness, religion, a thin skull, a large brain and language. Man ate the mushroom and learned to speak. Language is the only reality; reality is produced by language. Yet, inconsistently, this good deconstructionist goes on to say that "the psilocybin intoxication is a rapture whose breadth and depth is the despair of prose". But no matter. When a whole universe is compressed into the symbolic notations of 300 pages, one must expect a few inconsistencies. The main effect of psilocybin was in the domain of language. It "excites vocalization, empowers articulation, and transmutes language into something that is visibly beheld." In other words, if reality is language, and hallucination is language, then reality is hallucination. There is no reflecting mirror, no seeing through a glass darkly, no

.

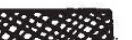
kick in refutation of nonexistence. Life is but a dream.

Language also makes us an epigenic species, a species whose future is determined not by genes but by culture, which in turn is determined by language. McKenna believes that language was created by the mutagenic action of hallucinogens on brain organelles involved in the processing of signals. Opening the doors of perception with drugs allowed the escape of utterance.

Africa has few hallucinogenic plants, and this, the author thinks, is the result of the fall of man: "Can it be mere coincidence that the longer an environment has been exposed to human beings, the fewer its native hallucinogens?" The apple, once eaten, is gone; a foretaste of the desolation that man has visited on the globe, and will continue to visit, unless he returns to his origins in the archaic period of 7,000-10,000 years ago, back to the turds and mushrooms and shamans, back to the strong silent hunt, alone with the mushroom visions and the wilderness, away from television and the seductive gossips around the vegetable patch.

Another two cents worth is added to the perennial soma controversy. Soma is the hallucinogenic preparation of the old Ayurvedic scripts of India that conferred immortality on its consumers. The source of soma has been variously identified as Ephedra, Cannabis, Peganum and Amanita (a

$\mathrm{m})$, as well as a herbarium of other plants. Here it is equated with our old friend Stropharia cubensis. Wasson's identification of soma as Amanita muscaria is challenged by McKenna on the grounds, among others, that, unlike $S$. cubensis, $A$. muscaria does not grow on cow excrement. Indeed, he says, $S$. cubensis is thought to have originated in Thailand, which raises the unanswered question of why man, thrown out of Africa, ran out of mushrooms.

Accuracy of detail seems unimportant to such a vision. In correction of some of the numerous mistatements in the book, the cactus genus Lophophora does not include Sonara in its range, but comes from Chihuahua and parts of Texas; not all steroids are alkaloids; a substance found naturally in the body can still be a drug; and coffee was first used in Europe not in 1100 but around 1500, in Venice.

Upon a peak in Darien, the author gazes at the whole of human experience with a wild surmise. Judgements come 
thick, fast and sweeping, couched in the adjectival prose used by that moiety of North America not addicted to compound nouns: "Medieval Europe was one of the most constipated, neurotic, and women-hating societies ever to exist . . . ruled by gouty, beef-eating men wearing dresses." Or how about: "The grandeur of Rome was the grandeur of a pig sty masquerading as a military brothel"? Well, yes. Such statements are as impossible to disprove as they are to prove. For all its colour, such language is devoid of meaning. So again we conclude that this is an excursion into the

\section{Metamorphosis}

\author{
John C. Marshall
}

Pride and a Daily Marathon. By Jonathan Cole. Duckworth: 1991. Pp. 194. £14.99.

WHEN Gregor Samsa awoke one morning, he found himself unable to get out of bed; he could not control the movement of his limbs and, without vision, was even unsure of the position of his body: "When finally, in a kind of rage, he summoned all his strength and recklessly thrust himself forward he had mistaken the direction, striking the lower bedpost a violent blow, and the sharp pain he felt informed him that it was this lower part of his body that was perhaps the most sensitive at the moment." Kaf$\mathrm{ka}$ 's man had metamorphosed into a giant insect.

The transformation that befell Ian Waterman in 1971 was scarcely less horrifying. As a perfectly normal young man of nineteen, a skilled butcher, he took a new job in the island of Jersey, in the English Channel. The boss, impressed by his speed, accuracy and dedication, was about to offer him a junior partnership in the business. Then fate struck. After what initially seemed no worse than a bout of gastric flu, Waterman, like Samsa, found that he was incapable of controlling his body. In Pride and a Daily Marathon, the sympathetic neurophysiologist who befriended and helped him documents Waterman's progress over the next 20 years

I write 'helped' rather than 'treated' because Waterman's condition was totally intractable. He had suffered a neuropathy of the peripheral nervous system that deprived him of the ability to feel touch and of all proprioceptive and kinaesthetic sensation below the neck. Such information is coded by myelinated nerve fibres with a relatively large diameter and conduction velocity. It was these nerves that had been functionally destroyed by an inflammatory immune realm of morality rather than knowledge. It is a peculiarly American activity, this construction of manichaean universes balanced on conjecture and black boxes. Such holy simplicities are not for the cynical who can conceive of complexities having more than a unitary origin. But it is the simplicities of this book that provide both its moral force and intellectual weakness.

Ryan J. Huxtable is in the Department of Pharmacology, College of Medicine, University of Arizona, Tucson, Arizona 85724, USA.

reaction to an (unknown) infective agent.

Some sensations, mediated by smaller, slower, unmyelinated nerve fibres, remained: pain, temperature, deep pressure and muscle 'effort'. There was no disorder of the motor nerves; the ability to move per se was retained, with normal strength. But this skill is of limited utility if you do not know where your body is to begin with, which direction it is moving in, and where it has arrived at during the course of movement. Loss of the 'sixth sense' of limb position, static or dynamic, seemed to condemn Waterman to 'life' in a wheelchair with a body that was not his own and over which he had no control.

The story that Cole recounts is how Waterman, by sheer willpower, guts and persistence, learned to do almost everything that is normally achieved automatically by the inner senses. No physiological recovery has taken place, but Waterman now manages his body by visual feedback; he constantly monitors every movement by sight. What he can do in this fashion is nothing less than astound- ing. To most intents and purposes Waterman leads a normal working life, although to call it 'normal' is something of an insult to the supernormal effort and concentration that he requires to do anything. For a man who can collapse in a heap on the floor if he sneezes (and hence loses, albeit momentarily, visual contact with himself), the description of life as "a daily marathon" is a gross understatement.

Cole's book (which is really coauthored by Waterman himself) is a model of popular science writing. An intimate biography of Waterman is interwoven with sufficient anatomical and physiological information for the general reader to understand the basic neurology of the peripheral nerves and their disorders. During his rehabilitation, some members of the medical and paramedical professions were very helpful, whereas others showed little understanding of his efforts. But, unlike the Samsa household, Waterman's friends and family were a tower of strength. (Connoisseurs of coincidence will note that Waterman's mother is called Felice.) Above all, the story is a tribute to what Waterman describes as his "pride, bloody pride". $\square$

John C. Marshall is in the Neuropsychology Unit, University Department of Clinical Neurology, Radcliffe Infirmary, Oxford OX2 GHE, UK.

- Extending the tradition of writing about illness is The Law of White Spaces by Giorgio Pressburger, published last month by Granta. Part fact, part fiction, part autobiography, the book contains five beautifully crafted stories about doctors forced to confront "mysteries bigger than themselves". Price is £12.99. (To be published by Pantheon in this United States later this year.)

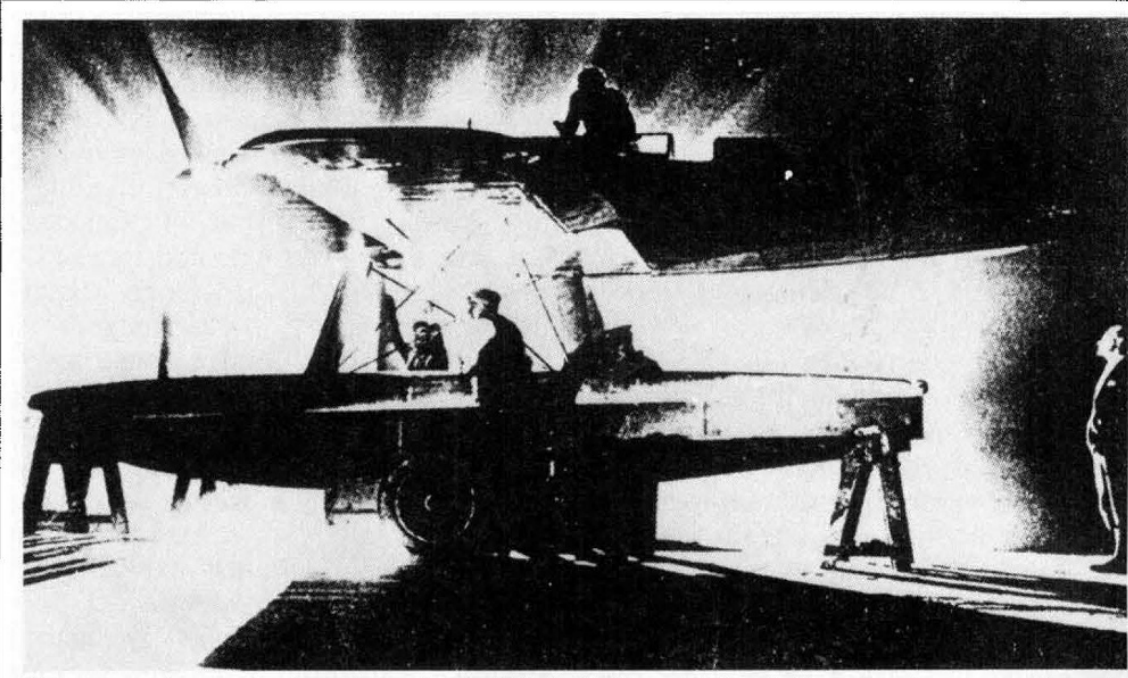

This aeroplane, designed by R. J. Mitchell (far right) at Supermarine, provides the clichéd image of English aviation, winning the world speed record in 1931 and being mistakenly portrayed as an early version of the Spitfire. In England and the Aeroplane, David Edgerton charts the history of English aviation, challenging current orthodoxy by arguing that England should be seen as a technological, industrial and militant nation. Published by Macmilian, £35 (hbk), £14.99 (pbk). 